\title{
基于现代教育技术环境下高职《机械制图》课程教学模式的 相关分析
}

冯琴

湖北职业技术学院

DOI:10.32629/mef.v2i2.66

[摘 要] 《机械制图》是机械工程的语言, 涉及到机械的设计、制造、维修等多方面,对将来从事机械行业的学生来说非常重 要。但是由于传统的高职《机械制图》棵程教学方法比较单一、落后, 而且教学棵程没有与实际的工程操作练习起来, 让学习 理解起来非常困难, 导致学生失去学习的积极性。而基于现代教育技术环境下高职《机械制图》课程教学模式的引入可以有 效改变这种教学现状, 大大提高教学质量和学生的学习效率。因此, 本文就对基于现代教育技术环境下高职《机械制图》棵程 教学模式做了一些相关分析。

[关键词] 现代教育；技术环境；高职院校；机械制图；教学模式

随着我国经济的快速发展, 以及新课程改革的背景下, 高职教育受到了广泛关注。而《机械制图》作为高职院校 机械技术的一门基础课, 对学生今后的学习和在以后的工 作中都是非常重要的。但是目前我国很多高职院校的《机 械制图》课程的教学效果不是很乐观, 已经毕业的学生普 遍存在在识图、绘图上的能力都不足的情况, 严重影响到 学生的就业率。因此, 国内外教育专家就针对这一现象不 断的进行研究和探索, 提出了在现代教育技术环境下《机 械制图》课程的需要改革观点。其中的改革内容明确指出 《机械制图》课程的改革需要从教学过程、教学原则、教 学组织形式、教学方法等方面着手, 去提高学生《机械制 图》的能力。

\section{1 传统高职《机械制图》课程教学模式分析}

1.1 教学方法传统, 教学手段落后

传统的教学方法比较单一,一般都是将教师作为课堂教 学的中心和主体。这种教学方式容易让学生太过于依赖教师, 大大阻碍了学生思维能力的发展, 而且课堂教学上也很少互
动, 不能让学生有参与感, 这容易让学生产生枯燥感, 从而失 去学习的兴趣。所以导致《机械制图》课程教学效果不好, 学生的学习效率低下。

\section{2 教材陈旧, 内容枯燥}

随着科技和经济的进步, 计算机已经在人们的生活中得 到普遍的应用, 这相当于给《机械制图》带来了一次技术革 新, 让《机械制图》课程教学不再像传统教学那样仅仅依靠 教师在讲台上用粉笔+板书的形式进行教学。但是《机械制 图》教材上却没用将这次技术革新体现在出来, 教材的内容 依然是比较陈旧、枯燥, 这样势必会降低学生的社会适应能 力, 从而失去学习的积极性。

\section{3 重理论, 轻实践}

在高职的《机械制图》课程教学过程中, 教师一般采用 的是手动式教学说明, 例如在讲解组合体的读图时, 教师会 徒将各种类型的组合体试图画在黑板上向学生进行说明。但 是这种方式对教师的绘图能力要求比较高, 如果绘图水平差 话, 那么将会影响图形的表达, 从而影响学生看图能力的培

\section{4 结语}

中职学校应正确认识中职学生开展创业的前景和作用, 借助 “互联网+”技术和产生的各种平台开展实践活动。要 树立体系化理念, 根据专业特点进行创业教育课程体系的开 发和构建, 结合学校活动开展各种形式的创业锻炼活动; 建 立既懂理论, 又能操作的创业教育 “双师型” 教师队伍, 拓宽 思路, 为创业实践寻找更多的机会。

通过就业创业实践教育, 能为中职学校提高就业质量提 供新的思路, 丰富校园活动内容, 充分发挥中职学校学生特 点, 促进个人成长和家庭社会稳定, 具有积极的意义和作用。

\section{[参考文献]}

[1]何苗.互联网+背景下高校创新创业教育模式探究 [ J]. 校企合作,2016,(19):128-129.

[2]许会杰.互联网+大学创业实践教育模式探讨 [J].合 作经济与科技,2016,(18):166-167.

[3]孟爱丽.基于电子商务平台的中职学校创新创业教育 初探[J].教育现代化,2017,(42):362-363.

[4]张岩。“互联网十教育”理念及模式探析[J].中国高教 研究,2016,(2):70-73.

\section{作者简介:}

王楠(1987.07-), 女, 汉族, 河南焦作人, 硕士,助理讲师, 研 究方向: 电子商务。

\section{基金项目:}

本文系 2018 年度河南省大中专毕业生就业创业研究课 题 “互联网+时代下中职学校学生创业实践教育模式及策略 研究” (证书编号: 豫教【2018】04552 号)研究成果。 
养。而这种对于一些新的教师来说, 他们的绘图能力都是比 较弱的, 所以容易导致学生看图能力低下。

\section{2 基于现代教育技术环境下高职《机械制图》课程教学 改革方案}

2.1 调整目标, 注重能力提高

职业能力培养的目的是使学生具备高素质、实用型技术 人才所具必须的机械制图基本知识和基本技能, 并且可以运 用这些知识和技能去解决实际工作中的问题。所以, 高职院 校在制定《机械制图》课程教学改革方案时, 要调整目标, 注重学生能力的提高, 要求学生必须掌握这就方面的基础技 能:（1）掌握正投影法试图空间物体的理论和方法, 通过这个 学习可以有效的培养学生的空间立体感和构思创新能力; (2) 要掌握有关机械制图中用到的零部件标准规范, 并且还要熟 练掌握这些零部件图、装配图的看图方法这样可以培养学生 识别机械制图中所用的零配件和装备能力, 从而让学生在绘 制相关机械图时可以大大提高绘图效率; (3) 需要让学生多 加练习徒手机械绘图的能力, 以及计算机机械绘图能力; (4) 教师在教学过程中要注重学生自学能力的培养, 这样可以提 高学生的学习效率, 以及解决实际问题的能力, 从而增加学 生的竞争力。

2.2 改革教学内容, 满足能力培养需要

在现代教育技术环境下, 高职《机械制图》教学内容应 该要做一定的改革, 教学的内容要应以基础理论教学应用为 目的, 强化应用为教学的重点, 构建应用型教学内容体系, 加 强学生工程实践能力、工程素质、工程创新能力的培养。除 此之外, 为了提高学生的社会适应能力, 教学内容应该要紧 跟时代和科技技术的变化做出改革, 不断的引入新知识、新 技术, 去增加学生的应用能力。
2.3 改进教学方法, 提高教学质量

为了有效提高高职《机械制图》的教学质量和学生的学 习效率, 教师在课程教学中应该采用以教师为主导, 学生为 主体的教学模式, 再结合、启发式教学、分层次教学、成立 兴趣小组等多样化的讲学模式去激发学生的求知欲望和学 习兴趣, 这样可以有效提高学生的制图能力和识图水平。

\section{3 结束语}

总而言之, 基于现代教育技术环境下高职《机械制图》 课程教学模式的改革, 充分体现了当代工程教育 “突出实际 应用” 的价值取向。这种教学模式的改革有效的提高学生的 机械制图能力和试图水平, 从而增加了学生以后的工作竞争 力。

\section{[参考文献]}

[1]蒋晶晶, 陈本锋.高职院校机械制图课程的分层教学 探讨[J].西部素质教育,2017,3(10):142.

[2]王小娟,高洁.高职《机械制图》课程分层教学改革研 究[J].晋城职业技术学院学报,2013,6(3):52-54。

[3]张栋栋,刘斌。构建德育寓于智育的空间促进德智和 谐发展一一以概率论与数理统计为例 [J]. 吉林化工学院 报,2017(2):47-50.

[4]范光宇.基于《机械制图》课程的高职学生翻转课堂 学习方式实践[J].科技展望,2015(14):169.

[5]阙宝朋,刘英杰,杜文龙.SPOC 环境下基于翻转课堂的 混合式教学实践与反思——高职《计算机网络基础》课程 教学为例[J].中国教育信息化・基础教育,2017(6):44-47.

\section{作者简介:}

冯琴(1979.2-), 女, 汉族, 湖北孝感人, 工程硕士, 讲师, 研究 方向: 机械工程。 